\title{
STUDIES ON CUCURBIT VIRUSES IN MADRAS STATE
}

\author{
IV. Some Aspects of the Relationships of Melon Mosaic Virus Strain \\ to Its Three Aphid Vectors \\ By K. Nagarajan, ${ }^{*}$ and K. Ramakrishnan, ${ }^{* *}$ F.A.Sc.
}

Received March 23, 1971

\begin{abstract}
Melon Mosaic Virus (MMV) was non-persistent in its three aphid vectors. The pre-acquisition fasting threshold, acquisition threshold and the inoculation feeding threshold were 5 minutes, 10 seconds and 60 seconds respectively for Myzus persicae, 15 minutes. 30 seconds and 3 minutes respectively for Aphis gossypii, 60 minutes, 60 seconds and 5 minutes respectively for $A$, nerii. The optimum number of viruliferous aphids per plant for maximum, transmission was 30 in all the vectors. Increasing the number of aphids above this optimum decreased the percentage transmission of the virus. In the case of Myzus persicae, the reduction in the percentage transmission was conspicuous wien 240 aphids per plant were used whereas in $A$. nerii the decrease was noticed even when 100 aphids per plant were used. The percentage transmission by fasted aphids was more than by the non-fasted ones. Persistance of the virus during fasting was for 90,45 and 30 minutes respectively in $M$. persicae, $A$. gossypii and $A$. nerii while during feeding it was 30,15 and 10 minutes respectively. The aphid vectors were ranked in the following descending order of transmission efficiency: Myzus persicae, Aphis gossypii and $A$. nerii. The length of the pre-acquisition fasting period varied inversely as the efficiency. More efficient the vector, shorter was the fasting period. The acquisition threshold and incoulation feeding threshold also varied inversely as the efficiency of the vector. The fall in the efficiency of transmission when the number of aphid vector was increased above the optimum was considered to be due to a salivary inhibitor. Apterous forms of the aphid vectors were more efficient transmitters of the viruses than the alate forms.
\end{abstract}

* Pathologist, Sorghum Improvement Project, The Rockefeller Foundation, College of Agriculture. Rajendranagar, Hyderabad-30.

** Dzan and Additional Director of Agriculture, Agricultural College and Research Institute, Coimbatore 3. 
It was concluded that all aphids have a salivary inactivator, the quantity secreted varied from species to species, the efficiency of transmission being inversely correlated with the quantity of inhibitor secreted.

\section{INTRODUCTION}

A STRAIN of Melon Mosaic Virus occurs commonly on pumpkin (Cucurbita moschate Duch.) in Tamil Nadu. The virus was sap transmissible and also through three aphids, Hyzus persicae, Aphis gossypii and Aphis nirii. The present study was taken up to find out the relationship of the virus to the above vectors.

\section{Materials a:d Methoos}

The study on the virus-betor relationships ias carried out using an isolate of Melon Mosaic Virus. Virus-free colonies of aphid vectors, Myzus persicae, Aphis gossypii and A. nerii obtained by the multiplication of a single viviparous, wingless female were maintained on young healthy host plants in large insect-proof cages. Methods to determine the relationships were the same as described in detail by Nariani and Sastry (1962). Details are given under the respective experiments.

\section{RESULTS}

Preliminary investigations revealed that Myzus persicae, Aphis gossypii and $A$. nerii were the chief apnid vectors of transmission of the virus, the percentage transmission being 70,70 and 40 respectively while the following aphids, Aphis craccivora, A. maydis, A. malvae, Toxoptera citricidus, Breveconrye brassicae, Aluccophora intermedia and $A$. foveicollis, failed to trnasmit the virus strain.

(a) Effect of preliminary fasting on the efficiency of the aphid vectors to acquire the virus.-It was evident from the results that in all the three vectors a preliminary fasting was found necessary to effect successful transmission. However, the minimum fasting period required varied between the three vectors. In the case of Myzus persicae, a pre-acquisition fasting of 5 minutes was found sufficient for transmission of the virus while in the case of Aphis gossypii and A. nerii, the minimum pre-acquisition fasting was 15 minutes and 60 minutes respectively. However, in all the three vectors the percentage of transmission was comparatively low at the minimum preacquisition fasting. It was further observed that the optimum period of $n^{2}=$-acquisition fasting was 90 minutes for the three vectors, the percentage transmission of the viruses being $87 \cdot 50,62.50$ and $37 \cdot 50$ respectively. 
Fasting of the vectors longer than the ontimum was found to reduce the percentage of transmission in all the cases.

(b) To determine the acquisition threshold of the vectors.-The results indicated that the minimum time required by the vectors to pick up the virus from the infected plant (acquisition threshold) varied. While in the case of $M$. persicae the acquisition threshold was 10 seccnds, it was 30 and 60 seconds respectively in $A$. gossypii and $A . \cdot$ nerii. However, it was observed that the optimum acquisition feeding period was 5 minutes for all the 3 aphid vectors. The percentage transmission at 5 minutes acquisition feeding was $75 \cdot 00,62 \cdot 50$, and 50.00 respectively for $M$. persicae, A. gossypii and $A$. nerii. Longer acquisition feeding did not further improve the efficiency of transmission.

(c) To determine the inoculation threshold of the vectors.--The results indicated that the inoculation threshold of $M$. persicae was as short as 60 seconds while that of $A$. gossypii and $A$. nerii was 3 minutes and 5 minutes respectively. However, the percentage transmission was found to be poor with the above periods of feeding. The optimum period of inoculation feeding was found to be 60 minutes for all the three aphid vectors. Increasing the inoculation feeding period above 60 minutes reduced the efficiency of transmission.

(d) To determine the number of virulifercus aphids per plant required for efficient transmission.-The results of the experiment are presented in Table I.

It may be seen that in the case of $M$. persicae, a single viruliferous aphid per plant would result in successful transmission while in the case of $A$. gossypii and $A$. nerii, the minimum number of viruliferous aphids required per plant was 3 and 5 respectivey. However, it was observed that the optimum number of viruliferous aphids per plant required for maximum transmission was 15 in the case of $A$. gossypii and $A$. nerii and 20 in the case of $M$. persicae. It was also observed that colonization of the plant with more than the optimum number of aphids resulted in reduced percentage of transmission.

An important observations made from the above experiment was with regard to the number of viruliferous aphids per plant and the percentage transmission. The results showed that increasing the number of aphids per plant above the optimum resulted in reduced transmission. This observation was made for all the three aphid vectors, viz., $M$. persicae, A. gossypii and $A$. nerii tested. In order to find out the reasons for such reduction in 
the percentage transmission of the virus when large number of aphids per plant was used, further experiments were conducted using $M$. persicae and A. nerii as vectors and Cucubita pepo var. early white busit as test plant.

\section{TABLE I}

Minimum number of viruliferous aphids per plant for successfit sirus transmission

Pre-acquisition fasting ; 90 minutes

Acquisition feeding : 5 minutes,

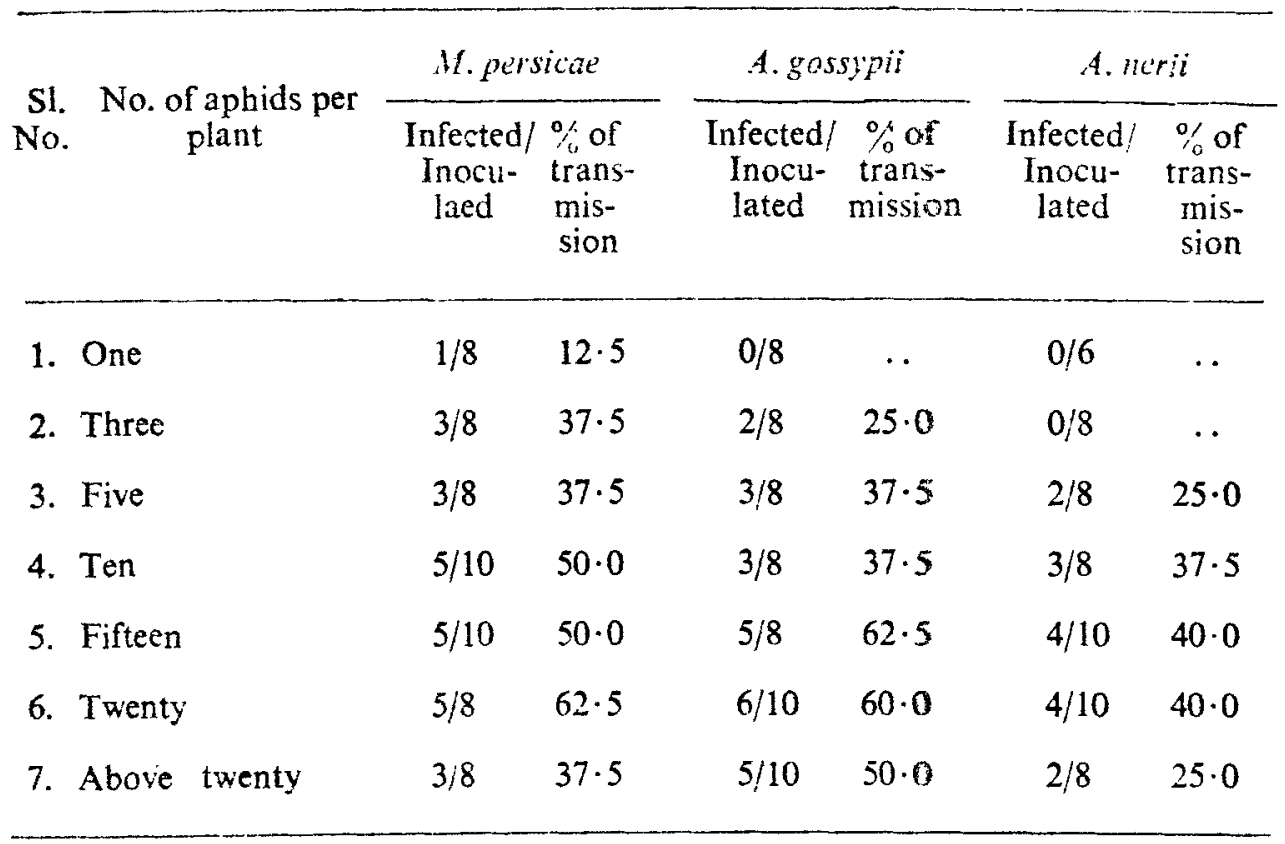

1. To find out the relation of number of viruliferous aphids per plant to percentage transmission of the virus isolate. Healthy colonies of Myzus persicae and Aphis nerii were collected and starved for 90 minutes. After the preliminary fasting, the vectors were fed for five minutes on young infected pumpkin leaf showing severe mosaic symptom. After the acquisition feeding, the viruliferous aphids were transferred to young healthy $C$. pepo plants at the rate of $10,20,30,40,60,80,100,120,240$ and 360 aphids per plant and allowed an inoculation feeding of 12 hours after which the plants were sprayed with parathion and kept inside an insect-proof glass house for observation. The results are presented in Table II. 
The results prosented in Table II further confirmed the earlier observation that increasing the number of virulifetous aphids per plant would decrease the percentage of transmission. In the present experiment it was found that the optimum number of viruliferous aphids per plant for maximum percentage of transmission was 30 to 40 in both $M$. persiccie and A. nerii.

\section{TABLE II}

Relation of number of viruliferous aphids per plant to percentage of transmission

\begin{tabular}{|c|c|c|c|c|c|c|c|c|}
\hline \multirow[b]{2}{*}{$\begin{array}{l}\text { Treat- } \\
\text { ment }\end{array}$} & \multirow[b]{2}{*}{$\begin{array}{c}\text { No. of } \\
\text { aphids } \\
\text { per } \\
\text { plant }\end{array}$} & \multirow[b]{2}{*}{$\begin{array}{l}* \text { a of } \\
\text { plants } \\
\text { used }\end{array}$} & \multicolumn{3}{|c|}{ Myzus persicae } & \multicolumn{3}{|c|}{ Aphis nerii } \\
\hline & & & $\begin{array}{l}\text { No. of } \\
\text { plants } \\
\text { infected }\end{array}$ & $\begin{array}{l}\text { trans- } \\
\text { mis- } \\
\text { sion }\end{array}$ & $\begin{array}{l}\text { Incu- } \\
\text { bation } \\
\text { period } \\
\text { in days }\end{array}$ & $\begin{array}{l}\text { No. of } \\
\text { plants } \\
\text { infected }\end{array}$ & $\begin{array}{c}\% \text { of } \\
\text { trans- } \\
\text { mis- } \\
\text { sion }\end{array}$ & $\begin{array}{l}\text { Incu- } \\
\text { bation } \\
\text { period } \\
\text { in days }\end{array}$ \\
\hline 1 & 10 & 15 & 8 & $53 \cdot 33$ & 8 & 4 & $26 \cdot 66$ & 9 \\
\hline 2 & 20 & 15 & 9 & $60 \cdot 00$ & 8 & 6 & $40 \cdot 00$ & 9 \\
\hline 3 & 30 & 15 & 11 & $73 \cdot 33$ & 8 & 7 & $46 \cdot 66$ & 10 \\
\hline 4 & 40 & 15 & 11 & $73 \cdot 33$ & 9 & 7 & $46 \cdot 66$ & 11 \\
\hline 5 & 60 & 15 & 10 & $66 \cdot 66$ & 9 & 5 & $33 \cdot 33$ & 11 \\
\hline 6 & 80 & 15 & 9 & $60 \cdot 00$ & 11 & 3 & $20 \cdot 00$ & 13 \\
\hline 7 & 100 & 15 & 9 & $60 \cdot 00$ & 11 & 3 & $20 \cdot 00$ & 14 \\
\hline 8 & 120 & 15 & 7 & $46 \cdot 66$ & 12 & 2 & $13 \cdot 33$ & 14 \\
\hline 9 & 240 & 15 & 5 & $33 \cdot 33$ & 14 & 2 & $13 \cdot 33$ & 14 \\
\hline 10 & 360 & 15 & 6 & $40 \cdot 00$ & 14 & 2 & $13 \cdot 33$ & 15 \\
\hline
\end{tabular}

Increasing the number of aphids above this optimum level resulted in a decrease in the percentage transmission. In both M. persicae and $A$. nerii the decrease started from treatment 5 onwards, and this was found to be gradual. The percentage transmission of the virus was decreased to 33.33 from 73.33 in the case of $M$. persicae when 240 aphids per plant were used and from 46.66 to 13.33 in the case of $A$. nerii when 120 aphids per plant were used. Further it was observed that larger the number of aphids per plant, longer was the 
incubation period. When the optimum number of aphids (30) per plant was used, the incubation period was 8 days in the case of $M$. persicae and 10 days in the case of $A$. nerii. When the number of aphids per plant was increased to 240 per plant, the incubation period with $M$. porsicae was 14 days and the percentage transmission was $33 \cdot 33$; in the case of $A$. nerii the incubation period was 14 days and the percentage of transmission was $13 \cdot 33$ only.

2. Detection of the salivary inhibitor.-This experiment was carried out to detect the salivary inhibitor, if any, of the aphid veciors, Myzus persicae and $A$. nerii, using healthy pumpkin leaves. The details of the experiment are given below:

Healthy pumpkin leaves were harvested from young, vigorously growing plants and leaf pieces (approx. $3 \cdot 5 \mathrm{sq} . \mathrm{cm}$.) weighing one gram were cut from each healthy leaf. Healthy colonies of the aphid vectors. $M$. persicae and A. nerii were selected and were transferred to the healthy leaf pieces, at the rate of 100,120 and 240 aphids per leaf piece. The aphids were used without any preliminary fasting. After allowing the aphids to feed on the healthy leaf pieces for 30 minutes, they were carefully removed. The leaf pieces thus fed with non-viruliferous aphids were macerated in one $\mathrm{ml}$. distilled water and mixed with one $\mathrm{ml}$. of virus infective sap (extracted from $1 \mathrm{~g}$. of infected leaf in $3 \mathrm{ml}$. of distilled water) and immediately inoculated on the test plants. Two ml. of the mixture obtained by mixing $i$ mil. of sap obtained from $1 \mathrm{~g}$. of healthy leaf and $1 \mathrm{ml}$. of virus-infective sap, was used to inoculate five test plants $(C$. pepo). The following were the treatments:

Treatment 1: Control-1 g. of virus-infected leaf macerated in $2 \mathrm{ml}$. distilled water.

2: Sap extracted from healthy leaf not fed with aphid vectors and mixed with equal quantity of virus-infected sap.

3: Sap extracted from healihy leaf bits fed with 100,120 and 240 non-viruliferous aphids, and mixed with equal quantity of virus-infective sap.

The results are presented in Table III.

The results presented in Table III indicate that in treatment 1 where virus-infective sap alone was used, the percentage of infection was 80.00. Further, symptom development was observed in 8 days. In tratment 2, when healthy sap was mixed with virus sap, the percentage of transmission 
was 66.66 and the symptom development was observed in 9 days. In treatment 3. when Myzus persicae was the vector, the percentage of transmission was $66 \cdot 66,66 \cdot 66$ and $53 \cdot 33$ respectively with 100,120 and 240 aphids per leaf. Further, it was observed that the incubation period was 10 days when 100 and 120 aphids were used and 12 days when 240 aphids were used. In the case of Aphis nerii, the percentage of infection with 100,120 and 240 aphids per lecf. was $66 \cdot 66,46 \cdot 66$ and $33 \cdot 33$ respectively and the incubation period was 10,10 and 14 days respectively.

TABLE III

Detection of the salivary inhibitor in vivo

\begin{tabular}{|c|c|c|c|c|c|c|c|}
\hline \multirow{3}{*}{\multicolumn{2}{|c|}{$\begin{array}{l}\text { Treat- } \\
\text { ments }\end{array}$}} & \multicolumn{6}{|c|}{ No. of aphids per leaf } \\
\hline & & \multicolumn{3}{|c|}{ Myzus persicae } & \multicolumn{3}{|c|}{ Aphis nerii } \\
\hline & & 100 & 120 & 240 & 100 & 120 & 240 \\
\hline 1 & $12 / 15$ & . & .. & . & .. & .. & .. \\
\hline 2 & $10 / 15$ & . & .. & . & .. & . & $\therefore$ \\
\hline 3 & .. & $10 / 15$ & $10 / 15$ & $8 / 15$ & $10 / 15$ & $7 / 15$ & $5 / 15$ \\
\hline
\end{tabular}

Numerator $=$ No. of plants infected.

Denominator $=$ No. of plants moculated.

3. Effect of pre-acquisition fasting on salivary inhibitors.-In the above experiments it was coserved that Myzus persicae and Aphis nerii when used in large numbers (240) and also without any pre-acquisition fasting probably produced an inhibitor which resulted in reduced transmission. In the present studies, comparison was made between aphids fasted prior to acquisition and aphids not fasted prior to acquisition.

One set each of healthy colonies of the aphid vectors (Myzus persicae and $A_{i}$ his nerii) was selected and fed for 60 minutes on healthy pumpkin leaf at the rate of 240 aphids per $3 \mathrm{sq} . \mathrm{cm}$. leaf piece. After the feeding, the aphids were carefully removed and the leaf piece macerated in $1 \mathrm{ml}$. of distilled water. The extract was immediately mixed with $1 \mathrm{ml}$. of viruliferous sap (extracted by grinding $3 \mathrm{sq} . \mathrm{cm}$ leaf bit of virus-infected leaf in $1 \mathrm{ml}$. of distilled water) and test plants $(C$. pepo) were inoculated. The resultant mixture of $2 \mathrm{ml}$. of the sap was used to inoculate 5 test plants. 
In another set, the aphid vectors were fasted for two hours in empty petri plates after which they were fed on healthy pumpkin leaf pieces for one hour at the rate of 240 aphids per 3 sq.cm, leaf bit. After one hour of feeding, the aphids were removed and the leaf bit was macerated in $1 \mathrm{ml}$. of distilled water, mixed with $1 \mathrm{ml}$. of virus sap as in the above case and then resultant mixture was inoculated on five test plants. The following were the four treatments used:

Treatment 1: Control-1 g. of infected leaf macerated in $2 \mathrm{ml}$. of distilled water (standard extract).

" 2: Healthy pumpkin leaf of $3 \mathrm{sq} . \mathrm{cm}$. macerated in $1 \mathrm{ml}$. distilled water and mixed with $1 \mathrm{ml}$. of the standard extract of the virus sap.

" 3 : Healthy pumpkin leaf piece of $3 \mathrm{sq} . \mathrm{cm}$. fed for one hour with aphid vectors without preliminary fasting. The extract of one ml. of this sap was mixed with $1 \mathrm{ml}$. of virus sap.

" 4: Healthy leaf piece of $3 \mathrm{sq} . \mathrm{cm}$. fed for one hour with aphid vectors after a preliminary fasting of 2 hours. The extract of $1 \mathrm{ml}$. of this sap was mixed with $1 \mathrm{ml}$. of the virus sap.

The results presented in Table IV seems to indicate that when aphids were fasted and fed on leaves, less of the virus inhibitors are excreted into the leaf. In the case of Myzus persicae, the percentage infection was 60.00 when non-fasted aphids were used as against 73.33 when fasted aphids were used. As regards Aphis nerii, the percentage of infection was 41.70 in the case of non-fasted aphids.

TABLE IV

Effect of pre-acquisition fasting on salivary inhlibitor

\begin{tabular}{|c|c|c|c|c|c|c|}
\hline \multirow{2}{*}{ Treatments } & \multicolumn{3}{|c|}{ M. persicae } & \multicolumn{3}{|c|}{ A. nerii } \\
\hline & $\begin{array}{c}\text { No. of } \\
\text { plants } \\
\text { inoculated }\end{array}$ & $\begin{array}{l}\text { No. of } \\
\text { plants } \\
\text { infected }\end{array}$ & $\begin{array}{l}\text { Percent- } \\
\text { age of } \\
\text { infection }\end{array}$ & $\begin{array}{c}\text { No. of } \\
\text { plants } \\
\text { inoculated }\end{array}$ & $\begin{array}{l}\text { No. of } \\
\text { plants } \\
\text { infected }\end{array}$ & $\begin{array}{l}\text { Percent- } \\
\text { age of } \\
\text { infection }\end{array}$ \\
\hline 1 & 15 & 12 & $80 \cdot 00$ & 12 & 9 & $75 \cdot 00$ \\
\hline 2 & 15 & 11 & $73 \cdot 33$ & 12 & 9 & $75 \cdot 00$ \\
\hline 3 & 15 & 9 & $60 \cdot 00$ & 12 & 5 & $41 \cdot 70$ \\
\hline 4 & 15 & 11 & $73 \cdot 33$ & 12 & 8 & $66 \cdot 66$ \\
\hline
\end{tabular}


4. Detection of salivary inlibitor in the aphids-Cuctirbita pepo (var. early white bush) plants of uniform age were selccted. Plants having fully expanded first leaf were used for all the treatments. Healthy colonies of the aphid vectors (Myzus persicae and Aphis nerii) were made to feed directly on the first true leaf for one hour at the rate of 240 aphids per leaf. After one hour the aphis were removed and the leaf was immediately incculated with virus sap. In another set, the first leaf on which the non-viruliferous aphids (240 lios.) were fed for one hour, was subjected to the feeding of viruliferous aphids at the rate of 30 per leaf. The following were the treatments :

Treatment 1: Plants inoculated with virus sap only.

" 2 : Plants inoculated through viruliferous aphid vectors only. In this case, the aphid vectors were starved for two hours and then given an acquisiion feeding of five minutes after which they were transferred to the first true leaf of the test plants at the rate of 30 per piant.

,

3 : Plants pre-treated with non-fasted aphids and then sap inoculated. In this case, the test plants at the first true leaf stage were subjected to the feeding of non-fasted aphids for one hour at the rate of 240 per leaf. Leaves :his treated were immediately inoculated with virus sap.

" 4 : Plants pre-treated with non-fasted aphids vectors and then inoculated through viruliferous aphids. In this case as in treatment 3 , test plants were subjected to the feeding of non-fasted aphid vectors at the rate of 240 aphids per leaf for one hour after which the leaves were subjected to the feeding of viruliferous aphids at the rate of 30 per plant.

No significant differences in percentage infection were noticed between Treatments 1-3. However, in treatment 4, conspicuous reduction in the percentage transmission by both $M$. persicae and $A$. nerii was noticed. Further, it was confirmed that $A$. nerii was a less efficient vector compared to $M$. persicae. The reduction in the percentage of infection in Treatment 4 might be due to the presence of inhibitor injected by the non-fasted aphids into the leaf. However, this reduction was not noticeable in Treatment 3 where also the leaves were subjected to feeding of the non-fasted aphids but inoculated with sap. 
The resu'ts are presented in Table $\mathrm{V}$ below:

TABLE $V$

Effect of salivary inhibitor on the transmission of the virus

\begin{tabular}{|c|c|c|c|c|c|c|c|}
\hline \multirow{2}{*}{\multicolumn{2}{|c|}{ Treatments }} & \multicolumn{3}{|c|}{ Mr. persicas } & \multicolumn{3}{|c|}{ A. nerii } \\
\hline & & $\begin{array}{c}\text { No. of } \\
\text { plants } \\
\text { inoculated }\end{array}$ & $\begin{array}{l}\text { No. of } \\
\text { plants } \\
\text { infected }\end{array}$ & $\begin{array}{l}\text { Percent- } \\
\text { age of } \\
\text { infection }\end{array}$ & $\begin{array}{l}\text { No. of } \\
\text { plants } \\
\text { inoculated }\end{array}$ & $\begin{array}{l}\text { No. of } \\
\text { plants } \\
\text { infected }\end{array}$ & $\begin{array}{l}\text { Percent- } \\
\text { age of } \\
\text { infection }\end{array}$ \\
\hline 1 & $9 / 10$ & .. & $\therefore$ & . & . & . & $\cdots$ \\
\hline 2 & . & 10 & 9 & $90 \cdot 00$ & 10 & 4 & $40 \cdot 00$ \\
\hline 3 & . & 10 & 8 & $80 \cdot 00$ & 10 & 4 & $40 \cdot 00$ \\
\hline 4 & .. & 10 & 7 & $70 \cdot 00$ & 10 & 2 & $20 \cdot 00$ \\
\hline
\end{tabular}

(e) Persistence of the virus in the vectors during fasting.-The results showed that the persistence of the virus during fasting was 90 minutes after acquisition in Myzus persicae; 45 minutes after acquisition in Aphis gossypii and 30 minutes in $A$. nerii. It was also observed that the rate of loss of the virus was gradual in the case of $M y z u s$ persicae while it was rapid in the other two aphid vectors.

(f) Persistence of the virus in the vectors during feeding.-The result indicated that the parsistence of the virus during feeding was much longer in $M$. persicale compared to $A$. gossypii and $A$. nerii. When the viruliferous aphid ( $M$. persicae) was transferred to a series of healthy test plants at an interval of 5 minutes, transmission was obtained till the fifth plant of the series. When the interval of transfer was 10 minutes between the plants, transmission was secured till the third plant of the series. This clearly indicated that the persistence of the virus in $M$. persicae during continuous feeding was 25 to 30 minutes as against 90 minutes during fasting. In the case of $A$ gossypii when three viruliferous aphids per plant (which was found to be minimum for transmission) were used, the persistence of the virus during feeding was 10 to 15 minutes as against 45 minutes during fasting. As regats f. morit, the pusistence of the virus during feeding was only 10 minutes as against 30 minutes during fasting. 
(g) Comparative efficiency of alate and aptcrous forms of aphids.-The results indicated that both the alate and apterous forms of the aphids transmitted the virus isolate. However, the apterous forms were found to be more efficient vectors.

\section{DISCUSSION}

Reviewing the present results obtained in the study of ãphid-virus relationships of the Melon Mosaic Virus (MMV), we are inclined to support the salivary inhibitor hypothesis to account for the specificity of aphid vectors to their viruses.

Sylvester (1961) reported that with efficient vectors, the effect of preliminary fasting will occur rapidly, i.e., within 5 minutes of the time that the insects are removed from a feeding site. In an inefficient vector, on the other hand, the effects of preliminary fasting has been shown to accumulate over a period of hours. The present studies showed that a preliminary fasting of 5, 15 and 60 minutes are required for $M$. persicae, $A$. gossypii and $A$. nerii respectively to become viruliferous. This observation is in agreement with that of Sylvester (1961).

It has been observed that the length of the preliminary fasting pericd required varied inversely with the efficiency of transmission. In the most efficient vector, $M$. persicae, the length of preliminary fasting for the vector to become viruliferous was as short as 5 minutes while in the case of the least efficient vector, $A$. nerii, 60 minutes were required. When no preliminary fasting was given, none of the vectors acquired the virus. These observations could most conveniently be explained by postulating: (1) in nonfasted aphids the salivary inhibitor is present in sufficiently high quantities to inactivate the virus taken up during feeding. (2) during fasting the secretion of the inhibitor is reduced or even completely stopped, and (3) in the less efficient vector more of the inhibitor is secreted during feeding and, therefore, the fasting period has to be correspondingly prolonged to reduce the flow of the inhibitor.

It has been reported by many workers (Watson, 1936, 1938; Watson and Roberts, 1939, 1940; Sylvester, 1954; Day and Irzykiewicz, 1954) that preliminary fasting of the aphid vectors reduces the activity of the postulated salivary inhibitor. Sylvester (1961) reported that the concentration of labile virus inactivators in the saliva or alimentary canal is perhaps decreased by fasting. Earlier, Sylvester (1954) reported that the quantity and rate of production of inhibitor varies with the insect species and the 
inhibitor is common to all aphids and acts on all viruses in a similar manner. Experiments conducted with fasted and non-fasted $M$. persicae and $A$. nerii indicated that when non-fasted vectors were fed on healthy leaf picces and the leaf macerate mixed with the inoculum the percentage transmission was 60.00 and 41.70 respectively for $M$. persicae and $A$. nerii; when fasted aphids in a similar experiment were used the percentage was 73.33 and 66.66 respectively. It is presumed that the aphids while feeding injected saliva (and inhibitor) into the leaves and fasting reduced the quantity of inhibitor injected.

The acquisition threshold varied inversely as the efficiency of transmission. The most efficient vector $M$. persicae acauired the virus in 10 seconds while $A$. nerii, the least efficient one, acquired the virus in 60 seconds. Increasing the acquisition feeding period above the optinum decreased the percentage transmission. It has been reported by Watson and Roberts (1938), Day and Irzykiewicz (1954), Sylvester (1954), Bradley (1954, 1959), Nariani and Sastry (1962) that longer the aphid fed on the diseased plant, the less efficient it became as a vector. The fall in the percentage of infections with longer acquisition feeding periods has been explained by Watson and Roberts (1938) and Day and Irzykiewicz (1954) on the basis of production of inhibitors in insects during feeding. The differences in acquisition threshold could also be explained by postulating differences in quantity of inhihibitor secreted-the least efficient vector secreting larger quantities than the most efficient and, therefore, larger quantities of the virus are required to neutralize the inhibitor leaving a residue of transmissible virus.

Persistence of the virus in the vector was longer during fasting than feeding. This corroborates earlier studies on cucumber mosaic virus (Doolittle and Walker, 1928; Bhargava, 1951), potato virus $Y$ (Smith, 1931; Watson and Roberts, 1940), pea mosaic virus (Osborn, 1937), Henbane mosaic virus (Watson, 1938; Watson and Roberts, 1940), and lettuce mosaic virus (Kassanis, 1947). Day and Irzykeiwics (1954) observed that the duration of persistence of infectivity of aphids has a bearing on the inactivator hypothesis. During fasting, the viruses would have les; opportunity of coming in contact with a salivary inhibitor. During feeding some virus is wiped off the stylets but the very short survival time of viruses during feeding indicates that they are subjected to an additional inhibiting action. The results of the present study on persistence of the viruses in their aphid vectors seems to lend support to the ir activator hypothesis. Further, it was observed that in the eficient vector, $M$. persical, the persistence of the virus during fasting 
as well as feeding was always longer than in the inefficient vector, A. nerii. This seems to indicate that there are inherent differences between aphid species in the quantity or quality of inhibitor secreted.

Another interesting observation made in the present study was that when a larger number of viruliferous aphids above an optimum was used, there was a decrease in the transmission percentage. Additional experiments conducted with $M$. persicae and A. nerii and MMV showed that when 240 aphids per plant were used (optimum number per plant was 30 aphids) there was reduction in the percentage of transmission. It is suggested based on the results that the aphids inject an inhibitor into the leaf while feeding and there is an in viro inactivation of the virus in the leaf when the quantity of inhibitor injected exceeds an optimum. It is significant that fasted aphids produced less of this effect and in the less efficient vector ( $A$. nerii) this effect was produced with a small number of aphids than in the more efficient vector ( $M$. persicae).

The results presented here formed part of a Ph.D. thesis presented to the University of Madras by the senior author. We are thankful to the University for granting permission to publish this paper.

\section{REFERENCES}

Bhargava, K. S.

Bradley, R. H. E.

Duy, M. F. and Irzykiewicz, $\mathbf{H}$.

Doolittle, S. P. and Walker, M. N.

Kassanis, $B$.

Nariani, T. K. and Sastiy, K. S. M.

Osborn, H. T.

Smith, K. M.
.. "Some properties of four strains of cucumber mosaic virus," Ann. Appl. Biol., 1951, 38, 377-88.

. "Studies on the mechanism of transmission of potato virus $Y$ by the green peach aphic, Myzus persicae Sulz. (Homoptera: aphididae)," Canadian J. Zool.. 1954, 32, 64-73.

.. "Loss of virus from the stylets of aphids," Virology, 1959, 8, 308-18.

"O.x the mechanism of transmission of non-persistent phy:opathogenic virsur s of aphıds," Aust. J. Biol. Sci. 1954, 7, 251-73.

"Aphid transmission of cucurnber mosaic," Abstr. Phytopathology, 1928, 18, 143.

.. "Studies on dandelicn yellows mosaic and othr virus discases of lettuce," Anm. Appl. Biol., 1947, 34, 412-21.

"Studies on the relationship of chilli mosaic virus and its vector Aphis gossypii Glov.," Indian Phyroparh., 1952, 15, 173-83.

. "Studics on the transmission of pea virus 2 by aphids," Phyto. patholegy, 1937, 27, 589-603.

.. "Virus diceases of plants and their relationship with insict vectors," Biol. Rer., 1931, 6, 302-44. 
Sylvester, E. S.

Watson, M. A.
.. "Aphid transmission of non-persistrnt plant viruses with special refurence to Brassica nigra virus," Hilgardia, 1954, 23, 53-98.

.. "Transmission of plant viruses by aphids. Problems in the clarsificaticn of plant virus transmission by aphids," Recent Adv. Bot., 1961, pp. 517-22.

.. "Factors affecting the amount of infection obtaincd by aphid transmistion of the vrus Hy. III," Roy. Soc. London, Phil. Trnas., 1936, 226 B, 457-89.

.. "Further studies on the relationship between Hyoscyamus virus 3 and the aphid Myzus persicae Sulz., with sfecial reference to the effects of fasting," Proc. Roy. Soc. Lcndon, 1938, $125 \mathrm{~B}, 144-70$.

and Roberts, F.M. .. A comparative study of the transmission of Hyoscyamus virus 3, potato virus $Y$ and cucumber virus 1 by the vector Myzus persicae (Stilz.), M. circumflexiss (Buckton.) and Macrosiphum gei (Koeh.)," lbid., 1939, 127 B, 543-76.

.. "Evidence against the hypothesis that certain plant viruses are transmitted mechanically by aphids," Ann. Appl. Biol., $1940,27,227-33$. 